\title{
Consensus Guidelines on Practical Issues of Immunotherapy-Canadian Society of Allergy and Clinical Immunology (CSACI)
}

\author{
Eric Leith, MD; Tom Bowen, MD; Joe Butchey, MD; David Fischer, MD, FRCPC; \\ Harold Kim, MD, FRCPC; Bill Moote, MD, FRCPC; Peter Small, MD; \\ Don Stark, MD, FRCPC; Susan Waserman, MD
}

The Canadian Society of Allergy and Clinical Immunology (CSACI) guidelines for the use of allergen immunotherapy were first published in 1995; since then, updated guidelines have been published. ${ }^{1-3}$ The CSACI has reviewed this topic at its annual meetings and in its official publication. ${ }^{4}$ We hope that this "Consensus Guidelines on Practical Issues of Immunotherapy" will promote excellence in the practice of immunotherapy in Canada. ("Allergen immunotherapy" or "specific immunotherapy" has also been termed "allergen vaccine" by the World Health Organization and others. ${ }^{5,6}$ )

\section{Immunoglobulin E-Mediated Immune Response}

The early phase of the immediate hypersensitivity reaction results from the release of mediators from mast cells or basophils, the key effector cells in the allergic reaction. High-affinity receptors on mast cells and basophils bind immunoglobu-

E. Leith, Chair CSACI Immunotherapy Working Group, Chair CAAIF, Lecturer, Department of Medicine, University of Toronto, Toronto, Ontario; T. Bowen, Clinical Professor of Medicine and Pediatrics, University of Calgary, Calgary, Alberta; J. Butchey, Associate Professor of Medicine, University of Western Ontario, London, Ontario; D. Fischer, Adjunct Professor, University of Western Ontario, London, Ontario; H. Kim, Assistant Clinical Professor, McMaster University, Hamilton, Ontario, Adjunct Professor, University of Western Ontario, London, Ontario; D. William Moote, Division of Clinical Immunology and Allergy, University of Western Ontario, London, Ontario; P. Small, Associate Professor of Medicine, McGill University, Montreal, Quebec; D. Stark, Clinical $\operatorname{lin} \mathrm{E}(\mathrm{IgE})$. When a multivalent allergen binds its specific IgE, the high-affinity receptors are crosslinked, leading to a cascade of events that result in mast cell and basophil degranulation. The resulting mediators and growth factors are also associated with the late-phase allergic response and with chronic inflammation. Eosinophils and neutrophils are attracted by chemotactic factors to the site of an immediate hypersensitivity reaction; in chronic allergic reactions, mononuclear cell infiltrates are also found. The inflammatory response has features of cellular and humoral immunity, and it results from a network of interacting soluble mediators, cytokines, and chemokines. ${ }^{7}$

\section{Allergens Considered for Immunotherapy}

Randomized double-blind placebo-controlled (RDBPC) studies have shown that immunotherapy is effective for the treatment of allergic rhinitis, allergic asthma, and hypersensitivity to

Associate Professor, Department of Medicine, Division of Allergy \& Clinical Immunology, University of British Columbia, British Columbia; S. Waserman, Division of Allergy and Clinical Immunology, Associate Professor of Medicine, McMaster University, Hamilton, Ontario

Reviewers: Dean Befus, MD; Stuart Carr, MD; Zave Chad, MD; Charles Frankish, MD; Mark Greenwald, MD; Art Kaminker, MD; Paul Keith, MD; Tim Vander Leek, MD; Keith Payton, MD; Bob Schellenberg, MD; Gordon Sussman, MD; Peter Vadas, MD; Richard Warrington, MD Correspondence to:Dr Eric Leith, 331 Sheddon Ave., Suite 302, Oakville, Ontario L6J 1X8; e-mail: es_leithmd@hotmail,com

DOI 10.2310/7480.2006.00011 
insect stings. ${ }^{8}$ The efficacy of subcutaneous specific immunotherapy has been documented in RDBPC studies of allergic rhinitis (and usually conjunctivitis) induced by birch, grass, ragweed, and Parietaria pollens; house dust mite; cat; and Alternaria. ${ }^{2}$ The beneficial effects of immunotherapy on asthma have been shown in regard to grass and ragweed pollen, house dust mites, cat, Cladosporium, and Alternaria..$^{6,9}$ Venom immunotherapy has proven to be an effective treatment for individuals at risk of anaphylaxis from yellowjacket, wasp, honeybee, white-faced hornet, and yellow hornet stings. Recently, fire ant whole-body extract has become available for immunotherapy. ${ }^{10}$ Latex, peanut, and cockroach allergens are under investigation. ${ }^{11-13}$

\section{Skin Testing, Skin Testing Devices, and Specific IgE Measurement}

Once signs and symptoms consistent with an allergic disease have been identified, a skin test demonstrating allergen-specific IgE antibodies is the primary means of confirming the presence of specific sensitization. ${ }^{14}$ Prick/puncture and intradermal/intracutaneous skin tests provide a biologically relevant demonstration of an immediate hypersensitivity response in the skin. A wheal and/or flare reaction denotes a positive test.

In the prick test, a drop of allergen is placed onto the epidermis. The usual sites are on the volar surface of the lower arm and back. The prick/puncture is made with a single-point, multipoint, or bifurcated needle. Excess allergen is blotted off with tissue or gauze. The immediate wheal and flare reaction for the allergen tested is read within 15 minutes, the time to maximum wheal diameter. Individual test sites need to be far enough apart $(2-3 \mathrm{~cm})$ so that results do not overlap. Dermatographism can lead to a false-positive reaction; this emphasizes the importance of including a negative control. Medications with antihistaminic effects (such as antihistamines and tricyclic antidepressants) may cause a false-negative result; thus, a positive control (usually histamine) is necessary.
Allergen may also be administered intradermally with a 26- to 27-gauge needle; 0.01 to $0.05 \mathrm{~mL}$ are injected, and the results are read after 15 minutes. Minor changes in the volume of extract injected have a minimal effect on the diameter of the wheal and on erythema. Intradermal skin tests may be more affected by the actual concentration of antigen and therefore require significantly less antigen than a skin-prick test requires. ${ }^{15}$ Higher intradermal concentrations are associated with false-positive results; hence, skin-prick tests are considered to be more specific, with the exception of skin tests for insect venom and for penicillin. ${ }^{16}$

Arbitrary grading schemes for wheal and erythema size are often used. However, measurement of the wheal and erythema in millimetres is more consistent and is recommended. ${ }^{17}$

Allergy testing is considered a safe procedure, but anaphylaxis may occur rarely in highly sensitive patients. Emergency equipment and appropriate medications must be available for the treatment of potentially life-threatening reactions. An allergic reaction resulting from skin testing in a patient who is on $\beta$-blockers and possibly on angiotensin-converting enzyme inhibitors may be more enhanced and less responsive to treatment.

The use of different skin-prick test devices may affect the interpretation of the skin-prick test. ${ }^{18}$ Results obtained with a single needle, a bifurcated needle, or Morrow-Brown devices may not be exactly the same. The actual amount delivered into the skin varies between 0.42 and $0.82 \mathrm{~nL}$ and appears to be more dependent on characteristics of the patient's skin than on the device or on the skill of the operator. When performed by a trained individual, skin tests are highly reproducible. Studies comparing different devices are in progress. ${ }^{18,19}$ (All biologic testing has associated hazards, and appropriate precautions are suggested. Disposable testing devices are recommended.)

Allergen-specific IgE antibody may also be detected in the blood by a radioallergosorbent test (RAST). "Second-generation" RAST-type assays such as the Pharmacia ImmunoCAP system provide more quantitative, sensitive, and precise serum IgE antibody results.

The Phadebas RAST (Pharmacia, Sweden) was the first assay to report in vitro detection of 
Table 1 Clinical Diagnostic Sensitivity of Tests for Immediate Hypersensitivity

\begin{tabular}{llll}
\hline Allergen & Skin-Prick Test & Intradermal Skin Test & $\begin{array}{c}\text { Specific IgE } \\
\text { Measurement (RAST) }\end{array}$ \\
\hline Insect venom or drugs & Insufficient sensitivity & Preferred & $\begin{array}{c}\text { Complementary to } \\
\text { intradermal skin test }\end{array}$ \\
Latex & Standard & $\begin{array}{c}\text { Not recommended } \\
\text { (risk of anaphylaxis) }\end{array}$ & $\begin{array}{c}\text { Acceptable } \\
\text { Food }\end{array}$ \\
Acceptable & $\begin{array}{c}\text { Not recommended (false } \\
\text { positives, risk of } \\
\text { anaphylaxis) }\end{array}$ & $\begin{array}{c}\text { Acceptable } \\
\text { (false negatives) }\end{array}$ \\
Inhalants & Acceptable & (False positives) & $\begin{array}{c}\text { Acceptable } \\
\text { (false negatives) }\end{array}$ \\
\hline
\end{tabular}

Adapted from Hamilton RG, Adkinson NF. ${ }^{14}$

$\mathrm{IgE}=$ immunoglobulin $\mathrm{E}$; RAST = radioallergosorbent test.

specific IgE antibodies. The newer Pharmacia ImmunoCAP system uses a different matrix to bind the IgE with various monoclonal and polyclonal anti-IgE-detection antibodies. Nonisotopic labels have increased the shelf life of reagents, making assays simpler and free of radioisotopes. The newer assays produce a more quantitative and reproducible measurement than the earlier paper disk-based RAST produced. RAST and other in vitro assays may be less sensitive diagnostically than skin tests but may be helpful in certain clinical situations such as those requiring tests for food and venom..$^{20}$

Intradermal testing is performed for drug and venom allergy diagnosis when skin-prick tests may not be sufficiently sensitive. However, skinprick tests are preferred for inhalants because intradermal tests for these are associated with a higher rate of false positives. In vitro assays may be used to complement in vivo testing when there is concern about the risk of testing (eg, anaphylaxis) or difficulty in interpreting the skin test (eg, dermatographism, eczema, interfering medications). Skin-prick tests are recommended for the diagnosis of food allergy. ${ }^{14}$ In vivo skin tests have the advantage of expediency and lower cost and are usually performed first. It is critical to interpret the results in the context of the clinical history and findings ${ }^{21}$ (Table 1 ).

\section{Immunologic Effects of Specific Immunotherapy}

Specific immunotherapy (SIT) involves the subcutaneous administration of an increasing adequate dose of the specific allergen as a treatment of allergy. ${ }^{22}$ Its first use was in 1911, when Noon treated "pollinosis" by injecting small amounts of pollen extract under the skin of individuals who had hay fever. ${ }^{23}$ The technique's clinical efficacy (as determined by symptoms, medication scores, early- and late-phase skin responses, and allergen thresholds) has been demonstrated. ${ }^{24}$ The aim of SIT is to inhibit the IgE immune response directed toward the allergen while leaving the remainder of the immune response intact. Unlike many other allergy treatments, SIT targets the underlying cause of the condition. Currently, there are four main explanations for the mechanism of immunotherapy: (1) immune deviation from $\mathrm{T}$ helper 2 cell (Th2) to T helper 1 cell (Th1) response, (2) production of immunoglobulin $\mathrm{G}$ ( $\operatorname{IgG}$ )-blocking antibodies, (3) reduction in mast cells and eosinophils, and (4) production of regulatory $\mathrm{T}$ cells and cytokines.

The allergic reaction may reflect a Th2 response characterized by the production of $\operatorname{IgE}$ and the proallergenic cytokines interleukin (IL)4 and IL-5. Studies indicate that SIT induces a 
switch from a Th2 response toward a Th1 response, with a reduction in IL-4 and IL-5, an increase in IL-10, and the induction of interferon- $\gamma$-secreting cells. ${ }^{22,24-31}$ SIT affects cytokine production, but how it does this and how the alteration of cytokine production relates to clinical outcome remain to be determined.

The mechanism of SIT has also been explained by a shift in antibody production away from IgE and toward IgG. SIT causes an initial slight increase and then a mild decrease in allergenspecific IgE levels and blunts the seasonal rise in IgE. ${ }^{24}$ There is, however, a large increase in allergen-specific IgG, especially IgG4. This observation has led to the "blocking antibody" theory, in which the $\mathrm{IgG}$ competes with IgE for allergen binding. This prevents the allergen from crosslinking IgE and causing the activation of mast cells, basophils, or other IgE receptor-expressing cells. ${ }^{24}$ However, IgG4 production increases in all patients who receive SIT, regardless of their clinical response to SIT. ${ }^{24}$ Also, in rush SIT, the treatment is effective before IgG levels increase. ${ }^{32}$ Although IgG may play a role, the mechanism is more complex than the simple competition of IgG with IgE.

A more comprehensive explanation of the role of IgG as a blocking antibody may involve serum IgE-facilitated allergen presentation (SFAP). ${ }^{33,34}$ The concept that allergen-specific IgE may facilitate T-cell activation comes from the observation that when IgE is incubated with its specific allergen and then mixed with CD23expressing antigen-presenting cells (APCs), the minimal concentration of allergen required for $\mathrm{T}$ cell activation is reduced at least 1,000 -fold.$^{35} \mathrm{It}$ is thought that the $\operatorname{IgE}$ allergen complexes are bound by Fce receptors on APCs, leading to endocytosis, processing, major histocompatibility complex class II antigen presentation, and (ultimately) greater $\mathrm{CD} 4^{+} \mathrm{T}$-cell activation. ${ }^{35,36}$ The increase in allergen-specific $\operatorname{IgG}(\operatorname{IgG} 4)$ following SIT prevents the formation of allergen IgE complexes that would normally bind to Fce receptors, therefore preventing S-FAP. ${ }^{33,37}$ Indeed, IgGcontaining fractions of sera from patients receiving SIT (and not those from controls) have been shown to inhibit S-FAP of Bet v $1 .{ }^{33,34}$ The reduction in S-FAP has also been shown to reduce
IL-4, IL-5, and IFN- $\gamma$ production of Bet $\mathrm{v}$ 1specific $\mathrm{T}$ cells.$^{34}$ Therefore, in addition to the blocking-antibody concept of $\mathrm{IgG}$, the role of IgG in SIT and in the treatment of allergy may also be the result of the abrogation of S-FAP (leading to increased allergen threshold levels) and reduced late-phase reactions.

SIT has also been shown to reduce the number of mast cells and eosinophils. The number of metachromatic cells (a marker for mast cells) has been shown to be reduced in individuals responding to SIT. ${ }^{24}$ In a placebo-controlled human trial with grass pollen, it was shown that the number of mast cells after SIT was correlated with clinical response (seasonal symptoms) and the use of rescue medication. ${ }^{38}$ The reduction of mast cells lowered the immediate response to allergen and was associated with a reduction in IL-4, IL-5, and $\operatorname{IgE}$ and with the recruitment and activation of eosinophils. Whether reduced owing to lowered mast cell activity or through other mechanisms, eosinophil levels have also been shown to drop after SIT. ${ }^{24}$

SIT has also been shown to cause the induction of T-regulatory cells, specifically IL-10 ${ }^{+}$ $\mathrm{CD} 25^{+} \mathrm{CD}^{+}$and $\mathrm{CD} 8^{+}$regulatory $\mathrm{T}$ cells. These cells are known for their regulatory function in many diseases (especially autoimmune diseases) and for the production of IL-10 and transforming growth factor beta (TGF- $\beta$ ), two regulatory cytokines. There is evidence that SIT induces the production of both $\mathrm{CD} 25^{+} \mathrm{CD} 4{ }^{+} \mathrm{T}$ cells and regulatory $\mathrm{CD}^{+} \mathrm{T}$ cells, leading to immune tolerance and to the production of IL-10, an immunoregulatory cytokine.$^{24}$ Immunotherapy has been shown to cause local increases in cells positive for IL-10 messenger ribonucleic acid in nasal mucosa after 2 years of treatment. ${ }^{37} \mathrm{IL}-10$ reduces the levels of IL-4 and IgE synthesis. It also plays a role in class-switching to IgG4, leading to a decreased ratio of $\operatorname{IgE}$ to $\mathrm{IgG}$ and an increased ability of $\operatorname{IgG}$ antibodies to block IgE.$^{37}$ Although support for the production of IL- 10 and TGF- $\beta$ exists, other studies have not found a change in IL-10 or TGF- $\beta$ levels. This may suggest a state of anergy, rather than active suppression. ${ }^{24}$ The production of regulatory $\mathrm{T}$ cells, however, is strongly implicated in SIT. 
The exact mechanism of SIT has not been completely characterized. However, evidence supports the role of an immunologic skew from Th2 to Th1, the production of IgG-blocking antibodies, a decrease in mast cells and eosinophils, decreased early- and late-phase allergic responses, and the proliferation of regulatory $\mathrm{T}$ cells and cytokines. It is important to note that these events are highly integrated and that SIT results in a complex response rather than a straightforward mechanism.

SIT is highly effective in selected patients with IgE-mediated disease and sensitivity to one allergen or a limited number of allergens. It is the only antigen-specific immunomodulatory treatment in routine use. It has been shown to provide long-term benefit and is the only currently available treatment that modifies the natural history of allergic disease for at least several years after discontinuation. ${ }^{39}$

The efficacy and safety of SIT might be improved by novel strategies that directly target the T-cell response. These include genetically modified non-IgE-binding recombinant allergens, allergen-derived peptides, and novel Th1promoting adjuvants derived from bacteria, such as monophosphoryl lipid and immunostimulatory sequences. Results of further controlled trials are awaited. ${ }^{39}$

\section{Efficacy of SIT}

SIT is effective for perennial and seasonal allergic rhinitis, allergic asthma, and hypersensitivity to insects of the order Hymenoptera, including the fire ant. ${ }^{1}$ The clinical efficacy of SIT for allergic rhinitis and asthma, as determined by using potent and standardized extracts in carefully selected patients, is well documented ${ }^{5,40,41}$ Candidates for SIT include patients with symptoms induced by allergens, patients with sensitivity to a single allergen or a few allergens, and young patients without chronic irreversible changes in upper airways. ${ }^{3}$ The beneficial effects of SIT are limited to the specific allergens that are administered. There may be some effect in decreasing hypersensitivity to allergens whose antigens cross-react with the allergen administered. Improvement is dose dependent, and most available studies indicate that 4 to $12 \mu \mathrm{g}$ of the major determinant of allergen are usually required for an effective maintenance dose. ${ }^{4}$

Efficacy has been documented in the majority of well-designed RDBPC trials on the treatment of rhinitis caused by grass, ragweed, Parietaria, and mountain cedar. RDBPC studies have also shown that pollen SIT reduces respiratory symptoms and/or decreases asthma medication requirements in asthmatic patients with pollen sensitivity. ${ }^{3}$ There is some evidence that early allergen SIT may prevent the acquisition of new allergic sensitivities. ${ }^{42}$ There is much less information available with respect to mixtures of pollen extracts. Some older studies showed that treatment with multiple allergens may be successful, but this area requires further study. ${ }^{43}$

SIT with house dust mite (Dermatophagoides pteronyssinus and/or Dermatophagoides farinae) allergen has been shown to reduce symptoms and the need for asthma medications in patients with house dust mite allergy, as well as to inhibit the late-phase response and to increase the threshold dose required to elicit bronchial obstruction in allergen inhalation challenge studies. Numerous studies with house dust mite have demonstrated the effectiveness of SIT in decreasing the symptoms of perennial allergic rhinitis., 3,44

SIT with cat allergen has led to improvement in bronchial sensitivity in patients with cat-allergic asthma. SIT with dog dander may be less effective than SIT with cat dander because of significant variations between different breeds of dogs and because of the choice of allergens included in the therapeutic extract. ${ }^{45}$

SIT with fungal vaccines is problematic owing to the biologic variability within fungal species and the increased variability of the material available for vaccine formulation. Also, the patterns of exposure to fungal species are less appreciated. ${ }^{46}$ Two RDBPC studies have demonstrated that SIT with Cladosporium and Alternaria vaccines may be effective for rhinitis and asthma., ${ }^{3,5,47}$ Proteolytic enzymes in some fungal extracts may digest allergens in the pollen vaccines.

Immunotherapy for peanut, latex, and cockroach allergies is still experimental. ${ }^{10,12,42,43}$ 
Table 2 Allergen Mixes

\begin{tabular}{l}
\hline Allergens with high protease activity \\
Arthropods (dust mite) \\
Fungi (mould spores) \\
Allergens with low protease activity \\
Grass pollen \\
Tree pollen \\
Weed pollen \\
Animals (cat and dog allergens) \\
Other Allergens \\
Ragweed \\
Insect venoms \\
\hline
\end{tabular}

Adapted from Li JT et al. ${ }^{3}$

\section{Prescription of SIT}

SIT vaccines are individually prepared for each patient. The clinical efficacy of the vaccine correlates with the choice of allergen, method of allergen mixing, dose selection, method of administration, and other factors. When a qualified physician prescribes allergen SIT, all of these matters must be addressed in a clearly documented prescription (examples appear in previously published guidelines). ${ }^{8}$

For a specific prescription, the allergens selected are determined by a history of symptoms from exposure to the allergens, a knowledge of the aerobiology of the region, and supporting skin test results. ${ }^{48,49}$ Standardized allergens should be used if available, and the manufacturer of the allergen should be specified. Allergen mixing is often required to include all of the relevant allergens. More than one vaccine vial may be required to accommodate the various allergens of importance. Cross-reactivity of allergens, the optimal therapeutic dose for each allergen, and interallergen degradation must be considered when combining allergens (Table 2). ${ }^{3}$ A preservative must be specified for each vial, and there are advantages and disadvantages to specific preservatives. Glycerin $50 \%$ is the most effective but is associated with discomfort at the injection site. Other preservatives include human serum albumin with phenol, an antigen stabilizer.

The maintenance concentration is the highest concentration of an allergen extract or vaccine that is projected as the therapeutically effective dose, and it should be selected to deliver what is considered to be a therapeutically effective dose for each of its constituent components. The maintenance dose is the product of the concentration or potency of the vaccine multiplied by the volume of the maintenance dose injection. The maintenance dose of each allergen should be based on doses used in control studies (Table 3 ). ${ }^{3}$ The prescribing physician must specify the number of serial dilutions (usually 10-fold) for the build-up phase. Patients who are highly allergic should be started with weaker serial dilutions.

The dose build-up schedule should be included with each SIT prescription. Clear instructions should be provided to the administering physicians and nurses. Informed consent should be obtained from the patient before SIT is started. ${ }^{3}$

Table 3 Recommended Maintenance Doses of Allergen

\begin{tabular}{llll}
\hline Allergen & Dose & Dose, Major Allergen & $\begin{array}{l}\text { Maintenance } \\
\text { Concentration }(w / v)^{*}\end{array}$ \\
\hline Dermatophagoides pteronyssinus & $600 \mathrm{AU}$ & $7-12 \mu \mathrm{g}$, Der p 1 & $\mathrm{NA}$ \\
Dermatophagoides farinae & $2,000 \mathrm{AU}$ & $10 \mu \mathrm{g}$ Der f 1 & $\mathrm{NA}$ \\
Cat dander & $2,000-3,000 \mathrm{BAU}$ & $11-17 \mu \mathrm{g}$ Fel d 1 & $\mathrm{NA}$ \\
Grass (eg, timothy) & $4,000 \mathrm{BAU}$ & $7 \mu \mathrm{g} \mathrm{Phl} \mathrm{p} \mathrm{5}$ & $\mathrm{NA}$ \\
Short ragweed & $\mathrm{NA}$ & $6 \mu \mathrm{g} \mathrm{Amb} \mathrm{a} \mathrm{1}$ & $1: 100-1: 30$ \\
Other pollen & $\mathrm{NA}$ & $\mathrm{ND}$ & $1: 100-1: 30$ \\
Fungi, mould & $\mathrm{NA}$ & $\mathrm{ND}$ & $1: 100-1: 50$ \\
\hline
\end{tabular}

Adapted from Li JT et al. ${ }^{3}$

$\mathrm{AU}=$ allergy units; $\mathrm{BAU}=$ bioequivalent allergy units; $\mathrm{NA}=$ not applicable $\mathrm{ND}=$ not determined; $\mathrm{w} / \mathrm{v}=$ weight per volume .

*Based on a maintenance injection of $0.5 \mathrm{~mL}$. 


\section{Safety of SIT}

Allergic and nonallergic reactions from SIT may be local and systemic..$^{50}$ Large local reactions may occur with aqueous immunotherapy. Subcutaneous nodules from alum-adsorbed vaccine occur rarely. The incidence of adverse reactions has been reported to be up to $1.9 \%$ in SIT whereas the adverse reaction rate may be as high as $36 \%$ in rush protocols. Allergic and anaphylactic reactions may result from SIT ${ }^{51}$ Fatalities have been rarely reported in some studies. ${ }^{51-59}$

Other adverse reactions have included immune complex reactions, serum sickness, brachial plexus neuropathy, pemphigus vulgaris, and nonorganic reactions, but causality has not been definitely established in all cases. Collagen vascular and lymphoproliferative diseases are not caused by SIT but theoretically can be exacerbated after SIT. ${ }^{51-59}$

Anaphylaxis may be secondary to errors in dosage, the presence of symptomatic asthma, a high degree of hypersensitivity, accelerated or rush administration schedules, or injections given during periods of potential seasonal exacerbations of asthma or rhinitis. Precautions to minimize adverse reactions during SIT include the avoidance of $\beta$-blockers, a 30-minute observation period after injection, written and/or verbal guidelines to patients and health care professionals, the presence of a physician during the injection, and optimal treatment of systemic reactions. Standard forms and standardized allergen preparation and dispensing procedures are recommended. ${ }^{3,51,56-59}$ Fatalities after SIT can be reduced by strictly following practice guidelines on patient selection, postinjection observation, preinjection screening of asthmatic patients, and early treatment of anaphylaxis. ${ }^{60}$

The recommended equipment in settings where allergen SIT is administered includes stethoscopes and sphygmomanometers, tourniquets, syringes, hypodermic needles, large-bore needles, and set-ups for intravenous-fluid administration and oral airways. The recommended therapeutic agents include aqueous epinephrine hydrochloride $(1: 1,000)$ for intramuscular administration, oxygen, intravenous fluids, antihistamines, and corticosteroids. Intubation equipment and vasopressors for injection may be considered in selected clinical settings. ${ }^{51,59}$
The prompt recognition of systemic reactions and the immediate use of epinephrine are the mainstays of therapy.

\section{SIT in Young Children}

Skin testing is valid for detecting allergen-specific $\mathrm{IgE}$ in young children. Young children may be at increased risk for systemic reactions from SIT. In young children, psychological problems or adverse reactions may result from SIT. ${ }^{3,5,41,61}$ Studies have suggested that SIT may reduce the development of asthma in children who have seasonal rhinoconjunctivitis. ${ }^{3,62-65}$ The development of new unrelated sensitization in children may be inhibited by SIT treatment with a single allergen. ${ }^{3,66,67}$

\section{Practical Issues of SIT}

\section{Patient Selection}

The following should be considered when deciding who should receive SIT $^{68}$ :

- Patients with significant symptoms of IgEmediated rhinitis and/or asthma inadequately treated by other forms of therapy (ie, allergen avoidance and optimal pharmacotherapy) should receive SIT.

- Patients with rhinitis or asthma caused by allergens for which the clinical efficacy and safety of SIT have been documented by RDBPC studies should receive SIT.

- Early institution of SIT may prevent chronic inflammation, the development of asthma in rhinitis patients, and sensitization to additional allergens..$^{1-3}$

- Venom immunotherapy is the treatment of choice for the prevention of subsequent anaphylaxis in patients with previously documented venom allergy.

\section{SIT in Asthma Patients}

SIT may be administered to asthma patients if the following conditions apply ${ }^{1-3,40,69-79}$ : 
- There is clear evidence of a relationship between symptoms and exposure to an unavoidable allergen to which the patient is sensitive.

- Symptoms occur all year or during a major portion of the year.

- Pharmacologic control is inadequate due to lack of effect or compliance.

- Asthma is controlled.

\section{General Considerations}

General factors regarding SIT include the following:

- SIT has greater efficacy in younger patients.

- Therapy with a single allergen is preferred to therapy with multiple allergens.

- SIT is of high risk in asthmatic patients whose forced expiratory volume in 1 second $\left(\mathrm{FEV}_{1}\right)$ is $<70 \%$.

- SIT is effective for pollen and dust mite allergy.

- SIT is less effective for allergies to mould and animal dander.

- SIT is effective and well tolerated by children.

- SIT is usually not started in pregnancy, but maintenance doses may be continued in pregnancy, with caution.

- For elderly patients or patients with autoimmune or immunodeficiency diseases, SIT is considered only in selected circumstances (there is concern regarding treatment of adverse reactions in elderly patients with comorbid illness or theoretic exacerbation of an underlying immunologic disease).

\section{Administration}

Factors in the administration of SIT include the following:

- Aqueous extracts are administered on a perennial basis with a weekly or twice-weekly incremental build-up to achieve a maintenance dose, followed by injections of the maintenance dose every 2 to 4 weeks.

- Alum extracts may also be considered.

- Successful treatment is normally carried on for 3 to 5 years; consideration is then given to stopping.
- Preseasonal injections on an annual basis can also be effective for symptom control but are less effective for disease modification when compared to perennial immunotherapy.

- Premedication with antihistamines may be helpful in preventing local reactions.

- Injections of a single allergen is preferred to the use of mixes (in mixes, cross-reactivity, the optimal dose of each allergen, and enzymatic degradation have to be considered).

- Separation of aqueous extracts with high proteolytic enzyme activities (fungi, house dust mite, cockroach, and insect venom) from other extracts is recommended.

- Extracts should be stored at $4^{\circ} \mathrm{C}$, to reduce loss of potency.

- Dilute solutions lose potency faster than more concentrated vaccines, and expiration dates must be followed.

The following are further considerations for the administration of specific allergen immunotherapy:

- SIT must be administered under the medical supervision of personnel trained in its administration.

- Resuscitative equipment, medications (including epinephrine and diphenhydramine), and storage facilities for allergen extract and vaccines must be available.

- Concomitant medications such as $\beta$-blockers (and possibly ACE inhibitors) may complicate the response to reactions to SIT and should be evaluated before starting.

- After systemic reactions, the risks and benefits of SIT should be reevaluated.

- Adverse reactions must be evaluated individually.

- Adjustments of dose recommended after reactions, when new vials are to be used, after missed injections, and for seasonal exposure must be individualized.

- Each vaccine vial should be labelled with the relevant information (such as the patient's name, the allergen contents, dosage and concentration, and the expiration date).

- Changing to another primary care physician involves transferring to the new physician information regarding lot number, manufacturer, vaccine description, and history of any prior reactions. 


\section{Managing Patients' Expectations}

The following are considerations in the management of patients' expectations:

- It may take 1 to 2 years for initial clinical effects to be evident.

- Compliance with the administration schedule and reaching the prescribed maintenance dose are essential to achieving efficacy.

- Environmental controls must be followed, avoidance practiced, and appropriate pharmacotherapy used.

- To achieve efficacy, a maintenance dose administered for 3 to 5 years is sufficient and may then be stopped.

- Consent forms may be obtained.

- Information sheets may be helpful.

- Poorly controlled asthma is a contraindication to the administration of SIT.

- Inquiries about intercurrent illnesses and changes in medications should be made before the vaccine is administered.

\section{Allergic Reactions to Insect Venom}

Detailed reviews of hypersensitivity to insect stings have recently appeared in the literature..$^{68,80,81}$ SIT with the venom of stinging insects (specifically yellowjackets, yellow hornets, whitefaced hornets, wasps, and honeybees) is reported to be up to $98 \%$ protective in patients with previous anaphylactic reactions to these stinging insects. ${ }^{82,83}$ However, SIT is not indicated for children who experience urticaria alone with no other systemic symptoms or for patients who have only large local reactions. ${ }^{10,84}$ SIT with subcutaneous administration of $100 \mu \mathrm{g}$ of insect-specific venom every 4 to 6 weeks is currently recommended. ${ }^{9}$ SIT should be continued for 5 years for maximal benefit but can be stopped earlier if the results of skin tests and RAST are negative. ${ }^{10,85}$ Subgroups of patients who may be at greater risk (eg, honeybee-allergic patients, patients who have had previous severe or nearfatal reactions or who have had reactions during venom SIT) may warrant longer therapy. ${ }^{86}$ As found recently, patients with hypersensitivity to fire ants may be treated with whole-body extract for fire ant. ${ }^{68}$

\section{Novel Forms of SIT}

Understanding of the allergic immune response has led to ongoing research and the development of novel forms of immunotherapy. ${ }^{87,88}$

Traditional subcutaneous SIT has been shown to be efficacious but not to be without potentially life-threatening complications..$^{39,60}$ Novel forms of immunotherapy for allergic disorders have therefore been sought to improve the risk-benefit ratio. These forms have involved modification of the allergen and the investigation of noninjectable routes. ${ }^{39,89-97}$

Local nasal immunotherapy, local bronchial immunotherapy, oral immunotherapy, and sublingual immunotherapy have recently been developed as immunotherapy using newer delivery routes.$^{89-93}$ Anti-IgE therapy is now available in Canada, the United States, and other parts of the world. ${ }^{94-97}$ Novel strategies for immunotherapy include recombinant genetically modified allergen proteins, allergen-derived peptides, smaller peptide vaccines, novel adjuvants, and immunostimulatory sequences of deoxyribonucleic acid containing $\mathrm{CpG} .^{20,95,96}$

Sublingual-swallow SIT has been shown to be safe and efficacious for allergy to many pollens and allergy to house dust mites. ${ }^{98-115}$ One study comparing subcutaneous SIT with sublingual SIT in birch allergy patients showed similar efficacy in each. ${ }^{113}$ Most RDBPC trials of sublingual SIT have confirmed a clinical efficacy ranging from a 20 to $50 \%$ reduction in symptom or medication scores, a superiority to placebo, and an efficacy approaching or equal to that of subcutaneous SIT. ${ }^{93,95,113}$ The efficacy of sublingual SIT starting as late as 2 to 3 weeks before the ragweed season has been demonstrated. ${ }^{99}$ Sublingual SIT for house dust mite allergy and asthma has been shown to maintain clinical efficacy 4 to 5 years after discontinuation, similar to the long-standing effects of subcutaneous SIT for grass. ${ }^{101}$ Adverse events seem to be fewer than with subcutaneous SIT; oral and gastrointestinal irritations are the predominant ones and are mostly mild to moderate in severity. 
Severe events have not been reported..$^{93,100}$ The optimum dose, the frequency of administration, the number of seasons or length of time to be administered, and the mixing of antigens all need further clarification and study. Current effective doses range from 20 to 400 times the doses usually required in subcutaneous SIT. , $^{98-114}$ Sublingual SIT has come to be more frequently prescribed in Europe. The global cost savings to the health care system and patients' acceptance of risk versus benefit and cost versus benefit require ongoing study.

\section{CSACI Recommendations}

As a professional society, the CSACI has a responsibility (to its members and to the physicians and patients for whom it provides consultations and ongoing care) to develop guidelines for the safety and quality assurance of allergen SIT. The prescription and preparation of allergen SIT must follow accepted standards of practice. Treatment sets prepared in the allergist's facility must conform to recommended good manufacturing practices. The development of standardized forms, as recently recommended by other professional allergy societies, is suggested. ${ }^{3}$ Also, in conjunction with provincial and federal regulatory bodies, the CSACI should continue to recommend that the prescription and preparation of allergen SIT be undertaken by physicians with the appropriate expertise and qualifications. ${ }^{1,3,4,116,117}$

\section{Addendum}

The Royal College Specialty Committee in Clinical Immunology and Allergy recognizes that specific immunotherapy (SIT) is a skill that is unique to our specialty. The objectives for our training programs as well as our final in-training evaluation reports have recently been revised to incorporate SIT as a key technical and expert skill required of our trainees. Residents in our program must know the immunologic mechanisms of immunotherapy and its indications. They should be able to prescribe and adjust SIT treatment programs for patients with environmental and venom allergies.
SIT began as the only allergy treatment modality for physicians practicing almost 100 years ago, before pharmacologic therapy was available. It has remained a key component of allergy management since then. Scientific advances in recent years have helped to explain the mechanisms of action and to identify the relevant antigens and the allergic epitopes for determining the effectiveness of SIT. Treatment plans and the adjustment of dosage depending on the patient's conditions have become more uniform, and standardized antigens have improved the effectiveness of SIT.

All trainees in Royal College programs approved by the Canadian Society of Clinical Immunology and Allergy should have the knowledge to administer SIT to patients as an appropriate and effective treatment.

Dr. Donald Stark, Chair, Specialty Committee on Clinical Immunology and Allergy, Royal College of Physicians and Surgeons of Canada, Specialty Training Committee in Clinical Immunology and Allergy Recommendations on Immunotherapy

\section{References}

1. Canadian Society of Allergy and Clinical Immunology. Guidelines for the use of allergen immunotherapy. Can Med Assoc J 1995;152:1413-9.

2. Bousquet J, van Cauwenberge P, Khaltaev N. Allergic rhinitis and its impact on asthma. J Allergy Clin Immunol 2001;10(5 Pt 2):S147-336.

3. Li JT, Lockey RF, Bernstein IL, et al. Allergen immunotherapy: a practice parameter. Ann Allergy Asthma Immunol 2003;90:1-42.

4. Leith ES. Allergens and allergen immunotherapy-practical clinical applications. Can J Allergy Clin Immunol 2002;7:72-8.

5. Bousquet J, Lockey R, Malling H. WHO position paper. Allergen immunotherapy: therapeutic vaccines for allergic diseases. Allergy 1998;53 Suppl:54.

6. Bousquet J, Michel FB. Allergen immunotherapy: therapeutic vaccines for asthma. In: Lockey RF, Bukantz SC, Bousquet J, editors. 
Allergens and allergen immunotherapy. New York: Marcel Dekker Inc.; 2004. p. 511-28.

7. Shearer WT, Fleisher TA. The immune system. In: Adkinson NF Jr, Yunginger JW, Busse WW, et al, editors. Middleton's allergy principles \& practice. Philadelphia: Mosby Inc.; 2003. p. $1-14$.

8. Allergen immunotherapy: practice parameter, 2003. Available at: http://www.jcaai.org.

9. Frew AJ. Immunotherapy of allergic diseases. J Allergy Clin Immunol 2003;111 (2 Suppl):S712-9.

10. Portnoy JM, Moffitt JE, Golden DBK, et al. Stinging insect hypersensitivity: a practice parameter. J Allergy Clin Immunol 1999;103:964-80.

11. Slater JE. Latex allergens. In: Lockey RF, Bukantz SC, Bousquet J, editors. Allergens and allergen immunotherapy. New York: Marcel Dekker Inc.; 2004. p. 369-86.

12. Li XM, Sampson HA. Novel approaches to immunotherapy for food allergy. In: Lockey RF, Bukantz SC, Bousquet J, editors. Allergens and allergen immunotherapy. New York: Marcel Dekker Inc.; 2004. p. 663-79.

13. Helm RM, Pomes A. Cockroach and other inhalant insect allergens. In: Lockey RF, Bukantz SC, Bousquent J, editors. Allergens and allergen immunotherapy. New York: Marcel Dekker Inc.; 2004. p. 271-96.

14. Hamilton RG, Adkinson NF. Clinical laboratory assessment of IgE-dependent hypersensitivity. J Allergy Clin Immunol 2003;111: S687-701.

15. Belin LG, Norman PS. Diagnostic tests in the skin and serum of workers sensitized to Bacillus subtilis enzymes. Clin Allergy 1977;7:55-68.

16. Bernstein IL, Storms WW. Summary statements of practice parameters for allergy diagnostic tests. Ann Allergy Asthma Immunol 1995;75:543-625.

17. McCann WA, Ownby DR. The reproducibility of the allergy skin test scoring and interpretation by board certified/board eligible allergists. Ann Allergy Asthma Immunol 2002;89:368-71.

18. Carr WW, Martin B, Howard RS, et al. Comparison of test devices for skin prick testing. J Allergy Clin Immunol 2005;116:341-6.
19. Demolv P, Piette V, Bousquet J. In vivo methods for study of allergy. In: Adkinson NF Jr, Yunginger JW, Busse WW, et al, editors. Middleton's allergy principles \& practice. Philadelphia: Mosby Inc.; 2003. p. 631-43.

20. Hamilton RG. Laboratory tests for allergic and immunodeficiency diseases. In: Adkinson NF $\mathrm{Jr}$, Yunginger JW, Busse WW, et al, editors. Middleton's allergy principles \& practice. Philadelphia: Mosby Inc.; 2003. p. 611-30.

21. Nelson HS. Advances in upper airway diseases and allergen immunotherapy. J Allergy Clin Immunol 2004;113:635-42.

22. Bousquet J, Lockey R, Malling HJ. Allergen immunotherapy: therapeutic vaccines for allergic diseases. A WHO position paper. J Allergy Clin Immunol 1998;102:558-62.

23. Noon L. Prophylactic inoculation against hay fever. Lancet 1911;1:1572-3.

24. Durham SR, Hamid QA. Immunologic changes associated with allergen immunotherapy. In: Lockey RF, Bukantz SC, editors. Allergens and allergen immunotherapy. New York: Marcel Decker Inc.; 1999.

25. Sade K, Kivity S, Levy A, Fireman E. The effect of specific immunotherapy on T-cell receptor repertoire in patients with allergy to house-dust mite. Allergy 2003;58:430-4.

26. Durham SR, Till SJ. Immunologic changes associated with allergen immunotherapy. J Allergy Clin Immunol 1998;102:157-64.

27. Ledford DK. Efficacy of immunotherapy. In: Lockey RF, Bukantz SC, editors. Allergens and allergen immunotherapy. New York: Marcel Decker Inc.; 1999.

28. Walker C, Zuany-Amorim C. New trends in immunotherapy to prevent atopic disease. Trends Pharmacol Sci 2001;22:84-90.

29. Holgate ST, Broide D. New targets for allergic rhinitis - a disease of civilization. Nat Rev $2003 ; 2: 1-12$.

30. Secrist H, Chelen CJ, Wen Y, et al. Allergen immunotherapy decreases interleukin 4 production in CD4+ T cells from allergic individuals. J Exp Med 1993;178:2123-30.

31. Hufnagl K, Wagner B, Winkler B, et al. Induction of mucosal tolerance with recombinant Hev b 1 and recombinant Hev b 3 for prevention of latex allergy in BALB/c mice. Clin Exp Immunol 2003;133:170-6. 
32. van Neerven RJ. The role of allergen-specific $T$ cells in the allergic immune response: relevance to allergy vaccination. Allergy 1999;54:522-61.

33. van Neerven RJ, Arvidsson M, Ipsen $\mathrm{H}$, et al. A double-blind, placebo-controlled birch allergen vaccination study: inhibition of CD23-mediated serum-immunoglobulin E-facilitated allergen presentation. J Exp Allergy 2004;34:420-8.

34. van Neerven RJ, Wikborg T, Lund G, et al. Blocking antibodies induced by specific allergy vaccination prevent the activation of $\mathrm{CD} 4+\mathrm{T}$ cells by inhibiting serum-IgE-facilitated allergen presentation. J Immunol 1999;163:2944-52.

35. van der Heijden FL, Joost van Neerven RJ, van Katwijk M, et al. Serum-IgE-facilitated allergen presentation in atopic disease. J Immunol 1993;150:3643-50.

36. Maurer D, Ebner C, Reininger B, et al. The high affinity $\operatorname{IgE}$ receptor $(\mathrm{Fc} \in \mathrm{RI})$ mediates IgE-dependent allergen presentation. J Immunol 1995;154:6285-90.

37. Nouri-Aria KT, Wachholz PA, Francis JN, et al. Grass pollen immunotherapy induces mucosal and peripheral IL-10 responses and blocking IgG activity. J Immunol 2004;172:3252-9.

38. Durham SR, Varney VA, Gaga M, et al. Grass pollen immunotherapy decreases the number of mast cells in the skin. Clin Exp Allergy 1999;29:1490-6.

39. Till SJ, Francis JN, Nouri-Aria K, Durham SR. Mechanisms of immunotherapy. J Allergy Clin Immunol 2004;113:1025-34.

40. Nicklas RA, Bernstein IL, Blessing Moore J, et al, editors. Practice parameters for allergen immunotherapy. J Allergy Clin Immunol 1996;98:1001-1011.

41. van Cauwenerge P, Bachert C, Passalacqua G, et al. Consensus statement on the treatment of allergic rhinitis. Allergy 2000;55:116-34.

42. Fischer TJ, Gruchalla RS, Alam R, et al. Medical knowledge self-assessment program 2003. American Academy of Allergy Asthma and Immunology/American College of Physicians.

43. Nelson HS. Immunotherapy for inhalant allergy In: Adkinson NF Jr, Yunginger JW, Busse WW, et al, editors. Middleton's allergy principles \& practice. Philadelphia: Mosby Inc.; 2003. p. 1455-73.
44. Lofvist T, Agrell B, Dreborg S, Svensson G. Effects of immunotherapy with a purified standardized allergen preparation of Dermatophagoides farinae in adults with perennial allergic rhinitis. Allergy 1994;49:100-7.

45. Hedlin G, Graf-Lonnevig V, Heilborn H, et al. Immunotherapy with cat and dog dander extracts. IV. Effects of 2 years of treatment. J Allergy Clin Immunol 1991;87:955-64.

46. Salvaggio JE, Burge HA, Chapman JA. Emerging concepts in mold allergy: what is the role of immunotherapy. J Allergy Clin Immunol 1993;92:217-22.

47. Horst M, Hejjaoui A, Horst V, et al. Doubleblind, placebo-controlled rush immunotherapy with a standardized Alternaria extract. J Allergy Clin Immunol 1990;85:460-72.

48. Nelson HS. Preparing and mixing allergen vaccines. In: Lockey RF, Bukantz SC, Bousquet J, editors. Allergens and allergen immunotherapy. New York: Marcel Dekker Inc.; 2004. p. 457-79.

49. Weber RW. Patterns of pollen cross-allergenicity. J Allergy Clin Immunol 2003;112:229-39.

50. Leiberman P, Kemp SF, Oppenheimer J, et al. The diagnosis and management of anaphylaxis: an updated practice parameter. J Allergy Clin Immunol 2005;115:S483-523.

51. Bukantz SC, Lockey RF. Adverse effects and fatalities associated with subcutaneous allergen immunotherapy. In: Lockey RF, Bukantz SC, Bousquet J, editors. Allergens and allergen immunotherapy. New York: Marcel Dekker Inc.; 2004. p. 711-27.

52. Committee on safety of medicine. CSM update. Desensitization vaccines. $\mathrm{Br}$ Med J 1986;293:948.

53. Lockey RF, Benedict IM, Turkeltaub PC, Bukantz SC. Fatalities from immunotherapy (IT) and skin testing (ST). J Allergy Clin Immunol 1987;79:660-77.

54. Reid MJ, Lockey RF, Turkeltaub PC, PlattMills TAE. Survey of fatalities from skin testing and immunotherapy 1985-1989. J Allergy Clin Immunol 1993;92:6-15.

55. Reid MJ, Gurka G. Deaths associated with skin testing and immunotherapy (abstract). J Allergy Clin Immunol 1996;231:195.

56. Kemp SF. Adverse effects of allergen immunotherapy: assessment and treatment. In: 
Ledford DK, Lockey RF, editors. Immunotherapy: a practical review and guide. Immunol Allergy Clin North Am 2000;20:571-91.

57. Rogala B. Risk and safety of immunotherapy. Allergy 1998;53:473-6.

58. Vadas P. Prevention of anaphylaxis in the office setting. College of Physicians and Surgeons of Ontario Members Dialogue, 2001.

59. AAAAI position statement 25. Guidelines to minimize the risk from systemic reactions caused by immunotherapy with allergen extracts. J Allergy Clin Immunol 1994;93:811-2.

60. Bernstein DI, Wanner M, Borish L, et al. Twelve-year survey of fatal reactions to allergen injections and skin testing: 1990-2001. J Allergy Clin Immunol 2004;113:1129-36.

61. Ownby DR. Adinoff AD. The appropriate use of skin testing and allergen immunotherapy in young children. J Allergy Clin Immunol 1994;94:662-5.

62. Moller C, Dreborg S, Ferdousi HA, et al. Pollen immunotherapy reduces the development of asthma in children with seasonal rhinoconjunctivitis (the PAT-Study). J Allergy Clin Immunol 2002;109:251-6.

63. Jacobson L, Dreborg S, Muller C, et al. Immunotherapy as preventive allergy treatment (PAT) (abstract). J Allergy Clin Immunol 1996;198.

64. Casale TB, Amin B. Allergic rhinitis/asthma interrelationships. Clin Rev Allergy Immunol 2001;21:27-49.

65. Valovirta E. Can the natural course of allergy and asthma be changed by allergen vaccination? Allergy 1999;54:27-9.

66. Des Roches A, Paradis L, Menardo JL, et al. Immunotherapy with a standardized Dermatophagoides extract. VI. Specific immunotherapy prevents the onset of new sensitizations in children. J Allergy Clin Immunol 1997;99:450-3.

67. Wahn U. Immunotherapy in children. Curr Opin Allergy Clin Immunol 2002;2:557-60.

68. Levine MI, Lockey RF, editors. Monograph on insect allergy. 4th ed. American Academy of Allergy, Asthma and Immunology; 2003.

69. Boulet LP, Becker A, Berube D, et al. Summary of recommendations from the Canadian asthma consensus report. Can Med Assoc J 1999;161 Suppl:11.
70. Lemiere C, Bai T, Balter M, et al. Adult asthma consensus guidelines update 2003. Can Respir J 2004;11 Suppl A:9A-33A.

71. Abrahamson MJ, Puy RM, Weiner JM. Allergen immunotherapy for asthma. Cochrane Database Syst Rev 2003;4:CD001186.

72. Abrahamson MJ, Puy RM, Weiner J. Immunotherapy in asthma: an updated systemic review. Allergy 1999;54:1022-41.

73. A position paper of the Thoracic Society of Australia and New Zealand and the Australasian Society of Clinical Immunology and Allergy. Specific allergen immunotherapy for asthma. MJA 1997;167:540-4.

74. Woodhead M. Guidelines on the management of asthma. Thorax 1993;48 Suppl:1-24.

75. Creticos PS. The consideration of immunotherapy in the treatment of allergic asthma. J Allergy Clin Immunol 2000;105 Suppl:559-74.

76. National Asthma Education and Prevention Program. Practical guide for the diagnosis and management of asthma. 1997 NIH Publication No. 97-4053.

77. International Consensus Report on the Diagnosis and Management of Asthma. National Heart, Lung and Blood Institute; 1992. NIH Publication No.: 92-3091.

78. National Asthma Education and Prevention Program. Expert Panel report: guidelines for the diagnosis and management of asthma update on selected topics-2002. J Allergy Clin Immunol 2002;110:5:S1-219.

79. Global initiative for asthma. Global strategy for asthma management and prevention. 2003. NIH Publication No.: 02-3659.

80. Moffitt JE, Golden DB, Reisman RE, et al. Stinging insect hypersensitivity: a practice parameter update. J Allergy Clin Immunol 2004;114:869-86.

81. Golden DB. Insect sting allergy and venom immunotherapy: a model and a mystery. J Allergy Clin Immunol 2005;115:439-47.

82. Hunt KJ, Valentine MD, Sobotka A, et al. A controlled trial of immunotherapy in insect hypersensitivity. N Engl J Med 1978;299:157-61.

83. Freeman TM, Hylander R, Otiz A, Martin ME. Imported fire ant immunotherapy: effectiveness of whole body extracts. J Allergy Clin Immunol 1992;90:210-5. 
84. Mauriello PM, Barde SH, Georgitis JW, Reisman RE. Natural history of large local reactions from stinging insects. J Allergy Clin Immunol 1984;84:494-8.

85. Randolph CC, Reisman RE. Evaluation of decline in serum venom-specific IgE as a criterion for stopping venom immunotherapy. J Allergy Clin Immunol 1999;103:963-80.

86. Golden DBK, Kagey-Sobotka A, Lichtenstein L. Survey of patients after discontinuing of venom immunotherapy. J Allergy Clin Immunol 2000;105:385-90.

87. Platts-Mills TA, Mueller GA, Wheatley LM. Future directions for allergen immunotherapy. J Allergy Clin Immunol 1998;103:335-43.

88. Broide D. Malling HJ. Immunotherapy. Curr Opin Allergy Clin Immunol 2001;1:541-74.

89. Malling HJ, Abreu-Noqueira J, Alvarez-Cuesta B, et al. Local immunotherapy. Allergy 1998;53:933-44.

90. Frew AJ, Smith HE. Sublingual immunotherapy. J Allergy Clin Immunol 2001;107:441-4.

91. Malling HJ. Is sublingual immunotherapy clinically effective? Curr Opin Allergy Clin Immunol 2002;2:523-31.

92. Valovirta E, Passalacqua G, Canonica WG. Non-injection routes for immunotherapy for allergic diseases. In: Lockey RF, Bukantz SC, Bousquet $\mathrm{J}$, editors. Allergens and allergen immunotherapy. New York: Marcel Dekker Inc.; 2004. p. 607-23.

93. Wilson DR, Torres Limas M, Durham SR. Sublingual immunotherapy for allergic rhinitis: systemic review and meta-analysis. Allergy 2005;60:4-12.

94. Wahn U, Hamelmann E. Anti-IgE therapy. In: Lockey RF, Bukantz SC, Bousquet J, editors. Allergens and allergen immunotherapy. New York: Marcel Dekker Inc.; 2004. p. 625-40.

95. Norman PS. Immunotherapy: 1999-2004. J Allergy Clin Immunol 2004;113:1013-23.

96. Casale TB. Status of immunotherapy: current and future (editorial). J Allergy Clin Immunol 2004;113:1036-9.

97. Holgate S, Casale T, Wenzel S, et al. The antiinflammatory effects of omalizumab confirm the central role of $\mathrm{IgE}$ in allergic inflammation. J Allergy Clin Immunol 2005;115:459-65.

98. Canonica GW, Passalacqua G. Noninjection routes for immunotherapy. J Allergy Clin Immunol 2003;111:437-8.
99. Bowen T, Greenbaum J, Charbonneau Y, et al. Canadian trial of sublingual swallow immunotherapy for ragweed rhinoconjunctivitis. Ann Allergy Asthma Immunol 2004;93:425-30.

100. Andre C, Vatrinet C, Galvain S, et al. Safety of sublingual-swallow immunotherapy in children and adults. Int Arch Allergy Immunol 2000;121:229-34.

101. Di Rienzo V, Marcucci F, Puccinelli P, et al. Long-lasting effect of sublingual immunotherapy in children with asthma due to house dust mite: a 10-year prospective study. Clin Exp Allergy 2003;33:206-10.

102. Sabbah A, Hassoun S, Le Sellin J, et al. A double-blind, placebo-controlled trial by sublingual route of immunotherapy with a standardized grass pollen extract. Allergy 1994;49:309-13.

103. Feliziani V, Lattuada G, Parmiani S, et al. Safety and efficacy of sublingual rush immunotherapy with grass allergen extracts: a double-blind study. Allergol Immunopathol (Madr) 1995;23:224-30.

104. Purello-D'Ambrosio F, Gangemi S, Isola S, et al. Sublingual immunotherapy: a double-blind, placebo-controlled trial with Parietaria judaica extract standardized in mass units in patients with rhinoconjunctivitis, asthma, or both. Allergy 1999;54:968-73.

105. Pajno GB, Morabito L, Barberio G, Parmiani S. Clinical and immunologic effects of long-term sublingual immunotherapy in asthmatic children sensitized to mites: a double-blind, placebocontrolled study. Allergy 2000;55:842-9.

106. Cafferelli C, Sensi LG, Marcucci F, et al. Preseasonal local allergoid immunotherapy to grass pollen in children: a double-blind, placebocontrolled, randomized trial. Allergy 2000;55:1142-7.

107. Ariano R, Spadolini I, Panzani RC. Efficacy of sublingual specific immunotherapy in Cupressaceae allergy using an extract of Cupressus arizonica: a double-blind study. Allergol Immunopathol 2001;29:238-44.

108. Andre C, Perrin-Fayolle M, Grosclaude M, et al. A double-blind placebo-controlled evaluation of sublingual immunotherapy with a standardized ragweed extract in patients with seasonal rhinitis. Evidence for a dose-response relationship. Int Arch Allergy Immunol 2003;131:111-8. 
109. Litwin A, Flanagan M, Entis G, et al. Immunologic effects of encapsulated short ragweed extract: a potent new agent for oral immunotherapy. Ann Allergy Asthma Immunol 1996;77:132-8.

110. Vervloet D, Birnbaum J, Laurent P, et al. Safety and clinical efficacy of rush sublingual Juniperus ashei immunotherapy. Abstract 783. Proceedings of the EAACI 2003 Annual Meeting.

111. Van Deusen MA, Angelini BL, Cordoro KM, et al. Efficacy and safety of oral immunotherapy with short ragweed extract. Ann Allergy Asthma Immunol 1997;78:573-80.

112. Litwin A, Flanagan M, Entis G, et al. Oral immunotherapy with short ragweed extract in a novel encapsulated preparation: a double-blind study. J Allergy Clin Immunol 1997;100:30-8.

113. Khinchi MS, Poulsen LK, Carat F, et al. Clinical efficacy of sublingual and subcuta- neous birch pollen allergen-specific immunotherapy: a randomized, placebocontrolled, double-blind, double-dummy study. Allergy 2004;59:45-53.

114. Lombardi C, Gani F, Landi M, et al. Quantitative assessment of the adherence to sublingual immunotherapy. J Allergy Clin Immunol 2004;113:1219-20.

115. Bousquet J. Sublingual immunotherapy: from proven prevention to putative rapid relief of allergic symptoms. Allergy;60:1-3.

116. Terr A. Unproven and controversial forms of immunotherapy. In: Lockey RF, Bukantz SC, Bousquet $\mathrm{J}$, editors. Allergens and allergen immunotherapy. New York: Marcel Dekker Inc.; 2004. p. 703-10.

117. Small P, the Canadian Rhinitis Working Group. Rhinitis: a practical and comprehensive approach to assessment and therapy. 2004. [Draft] 